\title{
Early ontogenetic expression of specificity in a cnidarian-algal symbiosis
}

\author{
Mary Alice Coffroth ${ }^{1, *}$, Scott R. Santos ${ }^{1}$, Tamar L. Goulet ${ }^{2}$ \\ ${ }^{1}$ Department of Biological Sciences, State University of New York at Buffalo, New York 14260, USA \\ ${ }^{2}$ Department of Biology, University of Mississippi, Mississippi 38677, USA
}

\begin{abstract}
Most cnidarian-microalgae symbioses exhibit some degree of specificity in host-symbiont pairing. Among taxa with aposymbiotic larvae, specificity must be established each generation. Newly settled polyps of the gorgonians Plexaura kuna and Pseudoplexaura porosa rapidly acquired zooxanthellae, in both laboratory and field settings. Initial zooxanthella acquisition by polyps was non-selective and did not reflect adult host specificity. When placed in shallow backreef and forereef habitats, and on the deep forereef, newly settled polyps naturally acquired zooxanthellae belonging to Symbiodinium clades A, B and C (based on restriction fragment length analysis of small subunit ribosomal DNA). Over time the taxonomic diversity changed such that by 3 mo, the majority of polyps $(77 \%)$ harbored only algae belonging to Symbiodinium clade B, the same algal clade found in the adult hosts. A survey of naturally occurring juvenile gorgonians (those $10 \mathrm{~cm}$ or less) showed that all contained only algae belonging to Symbiodinium clade B at this life history stage. These data are the first to characterize the early ontogenic change in zooxanthella diversity and confirm models of specificity in cnidarians in which a broad group of dinoflagellates initially enter the host followed by a change in algal genotypes that leads to the specificity observed in the adult host.
\end{abstract}

KEY WORDS: Symbiosis $\cdot$ Zooxanthellae $\cdot$ Specificity $\cdot$ Coral $\cdot$ Cnidarian

Resale or republication not permitted without written consent of the publisher

\section{INTRODUCTION}

Symbioses, in which microorganisms contribute to the nutrition and defense of their hosts, are important in both marine and terrestrial communities. Some of these symbioses exhibit a high degree of host-symbiont specificity and there is often evidence for coevolution between the host and symbiont (Mitter et al. 1991, Chapela et al. 1994, Hinkle et al. 1994, Baumann et al. 1997, Peek et al. 1998, Provorov 1998, Clark et al. 2000). These symbioses redevelop in the ontogeny of individuals each generation and hosts must acquire their symbionts either by direct inheritance of the symbionts from the parental host (i.e. a closed system, vertical transmission) or by acquisition of new symbionts each generation from the environment (i.e. an open system, horizontal transmission). In closed systems,

*E-mail: coffroth@acsu.buffalo.edu where the symbiont is transferred from parent to offspring, symbiont specificity is readily retained. In an open system, the possibility that any symbiont may enter the association makes the maintenance of symbiont specificity even more intriguing. This paper is the first to characterize symbiont diversity during early ontogeny and using a cnidarian-algal symbiosis with horizontal transmission as a model system, establishes the ontogenic stage where the specificity displayed in the adult is established.

The most common symbionts in cnidarian-algal symbioses are dinoflagellates in the genus Symbiodinium, which are generally referred to as zooxanthellae. The taxonomic affinity of most zooxanthellae is unclear and the symbionts are often classified by the host taxon or more recently by restriction fragment length polymorphisms (RFLP) of the large and small subunit of ribosomal genes (i.e. zooxanthellae of Symbiodinium clades A through E; Rowan \& Powers 1991a,b, Darius et al. 
1998, Hill \& Wilcox 1998, Baker 1999, Carlos et al. 1999, Toller, Rowan \& Knowlton pers. comm.). At this level of taxonomic resolution, adult populations generally harbor the same symbiont type throughout the host's depth and geographic distribution (Schoenberg \& Trench 1980a, Baker \& Rowan 1997, Billinghurst et al. 1997, Baker 1999, Goulet 1999). For example, in the octocoral Plexaura kuna, all adults harbor zooxanthellae belonging to Symbiodinium clade B, regardless of where the host individual is found (depth or geographically, Goulet 1999). Zooxanthellae belonging to the other clades are present in cnidarians on the same reefs which implies specificity between $P$. kuna and Symbiodinium clade B zooxanthellae and implies a selection for clade B zooxanthellae at some point in the development of the symbiosis. The majority of octocoral and scleractinians species examined harbor a single algal clade suggesting specificity at least at the level of clade (Baker \& Rowan 1997, Baker et al. 1997, Billinghurst et al. 1997, Goulet \& Coffroth 1997a, Baker 1999, Goulet 1999). Several scleractinian species, however, harbor zooxanthellae from multiple clades and the distribution of zooxanthellae within some hosts changes in response to changes in depth and/or light (Rowan \& Knowlton 1995, Baker et al. 1997, Rowan et al. 1997, Rowan 1998, Baker 1999). Yet even among these host species, the pairing between host and symbiont is not random (Trench 1997, Rowan 1998).

Further evidence that specific pairing exists among adults and symbionts in many cnidarian species comes from in vitro infection studies that demonstrate that not all algal strains can colonize a given host. This suggests discrimination on the part of the host and/or symbiont (Trench 1971, Kinzie 1974, Schoenberg \& Trench 1976). In those experiments the native symbiont always performed best in the symbiosis (Kinzie 1974, Kinzie \& Chee 1979, Schoenberg \& Trench 1980b, Fitt 1985).

Although specificity in adult cnidarians is clear, how and when specificity is established has not been investigated under natural (field) conditions. In systems with horizontal transmission, the symbionts are acquired during early ontogeny either by the larvae or by the newly metamorphosed polyps. Many studies have characterized the initial acquisition of zooxanthellae by aposymbiotic larvae and newly settled polyps and the reacquisition of zooxanthellae by aposymbiotic (bleached) adults (Provasoli et al. 1968, Kinzie 1974, Fitt \& Trench 1981, Fitt 1984, Colley \& Trench 1985, Schwarz et al. 1999), but none have followed this event in a natural setting over extended periods. Trench $(1988,1997)$ and Douglas (1998) have suggested that many algal types initially enter the host and over time, less efficient and/or less competitive genotypes are replaced or displaced. However, this model of symbiosis has not been explicitly tested. Furthermore, no study has characterized the zooxanthella taxa that are initially acquired and compared those with the zooxanthellae that persist. To explain the patterns of zooxanthella distribution that we see in adult hosts, an understanding of what occurs under natural field conditions is needed. Do larvae and newly settled polyps take up single or multiple algal genotypes initially? Does selection for the zooxanthellae found in the adult host occur at this early stage? These data will indicate whether the symbiosis is dynamic in its early ontogeny and help to determine what governs the final outcome-environment, selection for efficient genotypes (Douglas 1998) or chance historical event.

In this study, we examine the ontogenetic expression of specificity in cnidarian-algal symbioses using gorgonian corals and their symbionts as a model system. These host species produce aposymbiotic larvae and the symbiosis must be established anew each generation. We followed in situ zooxanthella acquisition by aposymbiotic planulae of 2 octocoral species and identified the stage at which a stable symbiosis is established, that is the point at which the newly settled corals harbored the same type of zooxanthellae that the adult host normally harbors. We characterized the algal diversity and number of algal genotypes within newly settled recruits over time, and we also examined the effect of reef site on the types of zooxanthellae that initially colonize the host.

\section{MATERIALS AND METHODS}

Larval acquisition, rearing and maintenance. The Caribbean gorgonians Plexaura kuna and Pseudoplexaura porosa were used as sources of aposymbiotic planulae. Both species are gonochoric broadcast spawners that release gametes into the water 4 to $8 \mathrm{~d}$ after the summer full moons ( $P$. kuna, May through September, Brazeau \& Lasker 1989, Lasker et al. 1996; $P$. porosa, June through September, Kapela \& Lasker 1999). Branch tips from $P$. kuna and $P$. porosa were placed in aquaria with running seawater several days prior to spawning. On the evenings during spawning, the water flow was stopped, spawned eggs were collected from the surface of the tank and mixed with water taken from aquaria containing male branch tips (i.e. 'sperm water'). Bottles (0.5 or 1.0 l) containing eggs and sperm water were suspended in the sea overnight to provide regular and gentle stirring. Developing embryos were maintained in clean seawater until $3 \mathrm{~d}$ old. At this point the swimming larvae settled rapidly onto preconditioned plates (see 'Laboratory infection studies', in this section) and metamorphosed into polyps. 
Zooxanthella cultures and cell counts. Zooxanthella cultures were used to characterize diversity during early stages of infection and provided a controlled source of zooxanthellae for lab infection studies. The majority of cultures used in the experiments were isoclonal lines initially isolated from field infected polyps in June-August 1996. We followed standard protocols to isolate the zooxanthellae (Goulet \& Coffroth 1997b) and then used a dilution of the cultures to inoculate vials containing f/2 media (Guillard 1975) to an estimated final concentration of one cell/vial (Steen 1987). Zooxanthellae were grown in $\mathrm{f} / 2$ media in preconditioned artificial seawater and maintained under a 14:10 h light:dark cycle $\left(80 \mu \mathrm{mol} \mathrm{m}^{-2} \mathrm{~s}^{-1}\right)$ at $28^{\circ} \mathrm{C}$. Zooxanthellae were broadly classified as Symbiodinium clades A, B, C or unknown, based on restriction fragment length polymorphism (RFLP) analysis of ssRNA genes (Rowan \& Powers 1991b). The isoclonal lines were also used to estimate the minimum number of algal genotypes that initially establish a symbiosis with Plexaura kuna and Pseudoplexaura porosa.

Laboratory infection studies. Zooxanthella infection rates were assessed through laboratory experiments at the Smithsonian Tropical Research Institute's (STRI) field station in the San Blas Islands, Panama. One hundred $3 \mathrm{~d}$ old planulae were placed in 11 plastic containers $(\mathrm{n}=35)$ with an $8 \mathrm{~cm}$ diameter plexiglass settlement plate and $500 \mathrm{ml}$ seawater. The plates were conditioned by placing them in the field for 6 mo to $3 \mathrm{yr}$ to allow a coating of crustose coralline algae which induces settlement of gorgonian larvae (Lasker \& Kim 1996). When the majority of the planulae had settled onto the plates $(2 \mathrm{~d})$ and metamorphosed into the single polyp stage $(5 \mathrm{~d})$, 500 cells ml ${ }^{-1}$ of cultured zooxanthellae were added to each container, in order to assess zooxanthella infection rates under non-limiting concentrations. Algal cultures used had been maintained for 1 to $2 \mathrm{yr}$ and were derived from zooxanthellae isolated from newly-settled field infected polyps. The containers, with polyps, were maintained either under fluorescent lights or in indirect sunlight. Containers were rotated on a routine basis so each container received both fluorescent lighting and indirect sunlight. Every $2 \mathrm{~d}$ the water was changed, the location and infection status of each polyp was noted, and a new dose (500 cells ml ${ }^{-1}$ ) of algae was added. Four containers were maintained without the addition of zooxanthellae as controls for uptake of zooxanthellae from the water or encrusting biota on the plates. Establishment of the symbiosis was defined as the point at which the polyps became visibly infected, as evidenced by a pale greenish-brown color. To verify infection prior to the 'visibly' infected state, individual polyps were macerated in $200 \mu \mathrm{l}$ of $\mathrm{f} / 2$ media and zooxanthellae enumerated in 4 replicate samples using a hemocytometer.

In an attempt to ascertain the minimum zooxanthella concentration and exposure time required for successful infection, 2 experiments were conducted. In the summer of 1997, 100 three d old planulae were placed into each of 12 containers with preconditioned plates and $500 \mathrm{ml}$ of seawater. When the planulae were $5 \mathrm{~d}$ old, the majority had settled and metamorphosed into single polyps (91-171 polyps treatment ${ }^{-1}$ ) and algae (500 cells ml ${ }^{-1}$ ) was added to replicate containers for 2 , $4,6,9$ or $12 \mathrm{~d}$ over a period of $2 \mathrm{wk}$. The water in each container was changed every 2 to $3 \mathrm{~d}$ prior to addition of algae, so that the polyps were exposed to 500 cells $\mathrm{ml}^{-1}$ for as little as $2 \mathrm{~d}$ (i.e. 1 inoculation) or as long as $15 \mathrm{~d}$ (5 inoculations). Survival and infection status (as number visibly infected) were monitored every $2 \mathrm{~d}$. Every 2 to 3 d, 1 polyp from each treatment was macerated in $200 \mu \mathrm{l}$ of $\mathrm{f} / 2$ media and zooxanthellae enumerated. Four containers were maintained without the addition of zooxanthellae as controls for uptake of zooxanthellae from the water or encrusting biota on the plates. Experiments were terminated after $23 \mathrm{~d}$.

Results of the first experiment (see below) indicated that uptake occurred rapidly and that polyps could be infected by a low level of zooxanthellae present on the control plates or in the water. A second experiment was conducted during the summer of 1998 to control for the presence of zooxanthellae on the preconditioned plates, and to decrease the concentration and length of time polyps were exposed to zooxanthellae. This experiment was conducted at the STRI's field station in Bocas del Toro, Panama. Plexaura kuna planulae were reared as before and induced to settle in sterile 24 well microtiter plates in the presence of the phorbol ester, 12-tetra-decanoyl-phorbol-13-acetate (TPA, Henning et al. 1996). Single 3 d old planulae were rinsed 4 times in $0.2 \mu \mathrm{m}$ filtered seawater (FSW) and placed in wells of microtiter plates in $2.5 \mathrm{ml}$ of $0.2 \mu \mathrm{m}$ FSW (1 planula well ${ }^{-1}$ ). TPA was added to a final concentration of $8.1 \times 10^{-8} \mathrm{M}$ following the protocols of Henning et al. (1996). After $1 \mathrm{~d}$ of exposure to TPA, 75 to $100 \%$ of the polyps in each treatment had attached to the microtiter plates and 21 to $51 \%$ (mean, $39 \%$ ) had metamorphosed. The water in each well was then replaced with $2.5 \mathrm{ml}$ of $0.2 \mu \mathrm{m}$ FSW and the polyps exposed to 250 cells (i.e. 100 cells ml$^{-1}$ ) for 1,4 , $8,12,24,48 \mathrm{~h}$, or continuously (504 h) using a culture containing an equal mixture of zooxanthellae from Symbiodinium clades A and B (4 clade B isoclonal lines and 4 clade $\mathrm{A}$ isoclonal lines) with 24 polyps treatment $^{-1}$. After exposure to the algae for the given amount of time, the polyp and well were washed 4 times with $0.2 \mu \mathrm{m}$ FSW to remove any remaining zooxanthellae. Controls without the addition of zooxanthel- 
lae $(n=24)$ and controls for the exposure to methanol (the carrier used to dissolve TPA, $\mathrm{n}=24$ ) were also run. Water was replaced and the polyps scored for number visibly infected every $2 \mathrm{~d}$.

Field infections. To monitor in situ infection, $300 \times$ 3 day old planulae, along with plexiglass plates encrusted with coralline algae, were placed within 21 mesh-covered jugs (250 $\mu \mathrm{m}$ Nitex mesh) and then suspended on the reef, 1 to $2 \mathrm{~m}$ above the substrate at 3 sites in the San Blas Islands, Panama (13 to 14 jugs site $\left.^{-1}\right)$. This allowed planulae to settle on the settlement plates in situ. After 3 to $5 \mathrm{~d}$, the settlement plates, with metamorphosed polyps attached, were removed from the jugs and suspended vertically $0.5 \mathrm{~m}$ off of the substrate to prevent burial by sediment and grazing by benthic predators. Plates were placed in 3 reef environments, a shallow back reef site (BRS, $4 \mathrm{~m}$, number of polyps = 360), a shallow fore reef site (FRS, $6 \mathrm{~m}$, number of polyps $=512$ ) and a deep fore reef site (FRD, $17 \mathrm{~m}$, number of polyps $=358$ ). Plates were monitored approximately every $2 \mathrm{~d}$ for polyp survival and infection state (scored as the number visibly infected) for 2 mo. A subset of polyps was removed from the plates over the 2 mo period to monitor the inter- and intracladal variation among algae that entered the symbiosis. Polyps were preserved in $95 \%$ ethanol for molecular analysis $(\mathrm{n}=97)$, macerated for cell counts $(\mathrm{n}=44)$ or the zooxanthellae were isolated and put into culture $(n=68)$. At the end of the 2 mo period $(60 \mathrm{~d})$, the majority of the remaining polyps were removed. Some polyps, however, were left in the field and sampled at $3 \mathrm{mo}(90 \mathrm{~d})$ and again at 7 mo. To test for differences in infection rate between the field sites and between the field and the laboratory experiments, we compared the number of polyps visibly infected and not infected at each site and in the lab after polyps had been exposed to zooxanthellae for 19, 27, 37 and $46 \mathrm{~d}$ (randomly chosen days) using a chi-squared test of independence. A site with more visibly infected polyps than expected would imply that at this site polyps were being infected sooner or at a higher rate. At each site the number of polyps monitored for infection ranged from 122 to 390 , 57 to 279,24 to 148 , and 17 to 102 at 19,27, 37 and $46 \mathrm{~d}$ respectively. During this same period there were 220, 119,74 and 24 polyps, respectively, monitored in the lab experiments.

To assess the effects of exposure time using naturally available zooxanthellae, 3 day old planulae (with settlement plates available as substrate) were suspended over the reef in the mesh-covered jugs for 3 and $7 \mathrm{~d}$ at the BRS and FRS sites, respectively. After 3 and $7 \mathrm{~d}$, the settlement plates, with metamorphosed polyps, were transferred to the laboratory and maintained in $1 \mathrm{l}$ containers. The water in each container was changed every $2 \mathrm{~d}$ and survival and infection status were monitored.
We also sampled naturally occurring juvenile gorgonians (less than $10 \mathrm{~cm}$ ) to compare the zooxanthella types harbored at this life history stage with that found in newly infected polyps and adult gorgonians. Small gorgonians (a total of 10 species) were collected from 4 reefs in the San Blas Island, Panama (species included Briareum asbestinum, $\mathrm{n}=1$; Eunicea sp., $\mathrm{n}=1$; Muricea sp., n = 15; Plexaura flexuosa, n =1; Pseudoplexaura kuna, $\mathrm{n}=2$; Pseudoplexaura sp., $\mathrm{n}=6$; Pseudopterogorgia acerosa, $\mathrm{n}=6$; Pseudopterogorgia americana, $\mathrm{n}=1)$, 3 reefs near Bocas del Toro, Panama ( $P$. flexuosa, $\mathrm{n}=1$; $P$. americana, $\mathrm{n}=3$ ), 1 reef near San Salvador, Bahama (Pseudopterogorgia elisabethae, $\mathrm{n}=$ 10 ), and 1 reef in the middle Florida Keys (Eunicea sp., $\mathrm{n}=9$; Gorgonia sp., $\mathrm{n}=11$; Muricea sp., $\mathrm{n}=2$; P. flexuosa, $\mathrm{n}=1$; Pseudoplexaura $\mathrm{sp} ., \mathrm{n}=1$; P. acerosa, $\mathrm{n}=$ $1 ; P$. americana, $\mathrm{n}=58$ ). These reefs represent a range of reef types (back reef, forereef, patch reef) and environments (undisturbed, minimal anthropogenic influence to relatively heavily impacted coastal reefs.) We recorded height to the nearest $0.1 \mathrm{~cm}$ and collected a branch tip (up to $5 \mathrm{~cm}$, depending on the size of the colony). A small portion of each sample $(0.5$ to $1.0 \mathrm{~cm})$ was preserved in $95 \%$ ethanol for molecular analysis and the rest was air-dried for species identification.

Molecular analysis. Algal DNA was extracted from a small portion of adult colonies $(0.5 \mathrm{~cm})$ or entire newlysettled polyps following the protocols of Coffroth et al. (1992) and Goulet \& Coffroth (1997b). We used restriction fragment length polymorphism analysis (RFLP) of the small subunit of the ribosomal nuclear genes (ssrDNA) to distinguish among the zooxanthellae that initially infected polyps in situ. This region of the genome contains a range of domains evolving at different rates, which are extremely useful in characterizing phylogenetic relationships and have been used to characterize populations of zooxanthellae (Rowan 1991, Rowan \& Powers 1991a,b, 1992, Sadler et al. 1992, McNally et al. 1994, Zardoya et al. 1995, Carlos et al. 1999). RFLP analyses of zooxanthella ssrDNA followed the protocols of Rowan \& Powers (1991b) and Goulet (1999). Briefly, zooxanthella ssrDNA was amplified by PCR using the universal primer ss 5 and the dinoflagellate-biased primer ss3z of Rowan \& Powers (1991b). We followed the reaction conditions outlined in Rowan \& Powers (1991b), using 5 to 10 ng of DNA. PCR products (10 $\mu$ l volumes) were digested with the restriction enzymes TaqI and DpnII. The resultant fragments were separated on $2 \%$ TBE agarose gels to generate RFLP patterns. Zooxanthellae were classified as belonging to Symbiodinium clades A, B, or C based on comparison of the resultant RFLP patterns with RFLP patterns of cloned standards (Rowan \& Powers 1991b).

To examine algal identity at a finer scale than that of RFLP delineated clades, genotypes of a total of 40 zoo- 
xanthella clonal isolates, established from 10 Plexaura kuna polyps and 3 Pseudoplexaura porosa polyps (2 to 8 isolates polyp $^{-1}$ ) were compared using DNA fingerprints. Comparisons of these DNA profiles allowed us to examine within clade variation and the minimum number of algal genotypes that initially established a symbiosis with $P$. kuna and $P$. porosa polyps. Using the above techniques, algal DNA was extracted from each clonal isolate and used to generate DNA fingerprints following the protocols of Coffroth et. al (1992) and Goulet \& Coffroth (1997b). Briefly, the high molecular weight DNA was digested with the restriction enzyme HaeIII and the fragments separated on a $0.7 \%$ TBE agarose gel, running at $36 \mathrm{~V}$ for $36 \mathrm{~h}$. The DNA was transferred to a nylon membrane (Magna, MSI) and hybridized to the minisatellite probe, M13 using a nonradioactive, chemiluminescence hybridization procedure (Boehringer Manheim DIG non-radioactive nucleic acid labeling and detection system). The unbound probe was washed from the membranes and bound probe visualized using LumiPhos 480 (Life Codes Corporation). All zooxanthella clones isolated from a single polyp were run side by side on a single gel and the banding patterns were compared. Those zooxanthella clones that had identical DNA fingerprinting profiles (i.e. shared all bands) were scored as the same genotype, while those DNA profiles of isoclonal lines that differed by at least 1 fragment band were classified as a different zooxanthella genotype.

\section{RESULTS}

\section{Larval behavior}

In all experiments the majority of the larvae settled after $5 \mathrm{~d}$. As noted in other species, zooxanthellae were not required for polyp settlement and metamorphosis (Kinzie 1974, Benayahu et al. 1989, Lasker \& Kim 1996, Schwarz et al. 1999). After 19 to 28 d, sclerites were visible in many of the polyps and some of the polyps had begun to bud. Polyps exposed to zooxanthellae rapidly became infected (10 to $14 \mathrm{~d}$, see next section). Polyps that were not visibly infected also survived and developed in a similar manner to the visibly infected polyps (sclerites visible after $19 \mathrm{~d}$ ).

\section{Laboratory infection studies}

Zooxanthellae rapidly colonized polyps in laboratory infection studies (Fig. 1). Although polyps were not visibly infected (i.e. attained a pale greenish-brown color) until 10 to $14 \mathrm{~d}$, cell counts indicated that the symbiosis was established much earlier (Fig. 1). After 7 d, at

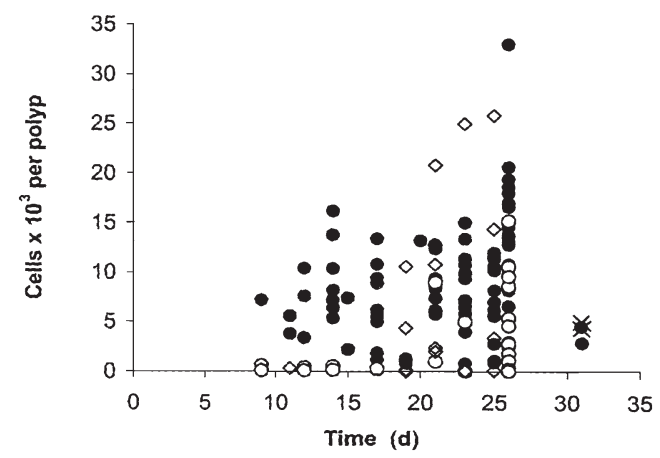

Fig. 1. (•) Number of zooxanthellae present in individual polyps under non-limiting concentrations $(500$ cells ml-1) in the lab, $\mathrm{n}=123$; (o) exposed to naturally occurring zooxanthellae in the field for 3 to $7 \mathrm{~d}, \mathrm{n}=28$; $(\diamond)$ with continuous exposure to zooxanthellae in the field, $\mathrm{n}=16$; $(\times)$ in 'no zooxanthellae added' controls, $\mathrm{n}=2$. Each point represents the number of zooxanthellae in a single newly settled polyp

the time of the first cell counts, an average of 813 cells per polyp \pm 1522 (mean $\pm \mathrm{SD}, \mathrm{n}=9$, range, 80 to 4800 cells) were present. At the time the polyps were visibly infected (at about $14 \mathrm{~d}$ ), polyps harbored between 2200 and 8000 cells (mean \pm SD, $6459 \pm 1806, n=9$ ) and after $21 \mathrm{~d}$, zooxanthella numbers within some of the polyps had reached $1.11 \pm 10^{4}$ cells polyp ${ }^{-1}$ (mean $\pm \mathrm{SD}$, $9400 \pm 3966, \mathrm{n}=17$ ). Polyps in 3 of the 4 control treatments, where no zooxanthellae were added, eventually acquired zooxanthellae after 17 to $31 \mathrm{~d}$. At $30 \mathrm{~d}$, visibly infected polyps in the control treatment harbored about half as many cells as the polyps that had been exposed to zooxanthellae in the lab over the same time period.

Additional experiments demonstrated that constant exposure to zooxanthellae is not necessary for successful establishment of the symbiosis. In the first infection time course experiment, metamorphosed polyps were exposed to zooxanthellae ( $500 \mathrm{cells} \mathrm{ml}^{-1}$ ) for as little as $2 \mathrm{~d}$. After $7 \mathrm{~d}$, randomly selected polyps from all of the treatments harbored zooxanthellae, regardless of time exposed to zooxanthellae. After $16 \mathrm{~d}$, at least some of the polyps in each treatment were visibly infected (32 to $89 \%, n=20$ to 85 ) and eventually the majority of polyps in all treatments were visibly infected (Fig. 2). Microscopic examination and cell counts indicated that all of the polyps sampled during the study contained zooxanthellae $(n=91)$. How rapidly a polyp appeared visibly infected, however, varied with time of exposure to zooxanthellae. The time polyps were exposed to zooxanthellae (i.e. the number of days zooxanthellae were added) was positively related to the proportion of polyps that were visibly infected (stepwise multilinear regression of arcsine transformed proportion infected polyps against days since first exposure and number of days exposed to zooxanthellae, $F=7.41, \mathrm{df}=2,17$; $p=0.005, r^{2}=0.466$, SPSS ver. 10.0). Thus, those treat- 


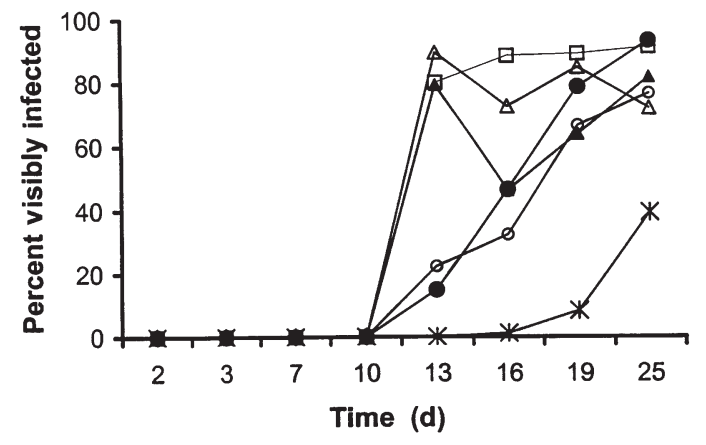

Fig. 2. The time until polyps appeared infected when exposed to zooxanthellae at a concentration of 500 cell ml-1 for $2(\circ)$, $4(\Delta), 6(\bullet), 9(\square)$, or $12(\Delta)$ d. The lower line $(*)$ shows the time course of infection of polyps maintained in the field

ments with more inoculations became visibly infected sooner (Fig. 2).

The final infection time course experiment, using TPA to induce larval settlement and metamorphosis, also demonstrated that constant exposure to zooxanthellae is not necessary for successful establishment of the symbiosis. Visible infection was first observed at $21 \mathrm{~d}$. The number of polyps surviving to $21 \mathrm{~d}$ (out of 24 initially) ranged from 6 to 21 in the 8 different treatments. Of these polyps, 9 to $56 \%$ were visibly infected at $21 \mathrm{~d}$ regardless of the time exposed to zooxanthellae (1 to 48 h or continuously, Fig. 3). There was no apparent relationship between the time a polyp was exposed to zooxanthellae in the experiment and the number of polyps that were infected after $21 \mathrm{~d}\left(\mathrm{r}^{2}=0.041, \mathrm{p}=\right.$ 0.431). Larvae settled rapidly in the presence of TPA, but polyps were rarely expanded and often misshapen. A similar developmental pattern was seen in polyps maintained in the microtiter plates, but not exposed to TPA. Finally, polyps incubated under the same conditions, but not exposed to zooxanthellae, remained aposymbiotic.

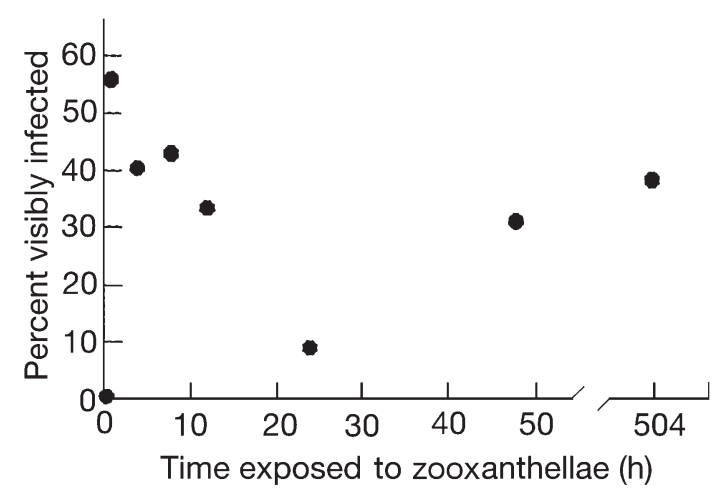

Fig. 3. Percentage of polyps that appeared visibly infected after $21 \mathrm{~d}$. Polyps were induced to settled in microtiter plates using TPA and exposed to 100 cells $\mathrm{ml}^{-1}$ for varying lengths of time $(1-504 \mathrm{~h})$
Field infection studies

In the field, where zooxanthella densities are probably lower than in the lab setting, polyps acquired zooxanthellae and became visibly infected within $17 \mathrm{~d}$ (Fig. 4). Polyps left in the field for 3 to $7 \mathrm{~d}$ and then transferred to the lab were visibly infected by 17 to 21 d (28 out of 71 polyps, 'field'; Fig. 2 ). Again, although not visibly infected, polyps sampled $7 \mathrm{~d}$ after exposure to zooxanthellae in the field, contained zooxanthellae (Fig. 1). Field polyps contained fewer zooxanthellae than polyps that were exposed to zooxanthellae in the laboratory experiment over the same time period (Fig. 1). The time required for field polyps to become visibly infected was comparable to those laboratory experiments in which lower concentrations of zooxanthellae were used. In general, during the establishment of the symbiosis, polyps exposed to zooxanthellae in the lab contained more zooxanthellae than polyps exposed to zooxanthellae in the field (significant difference between lab and field counts, ANOVA with days as covariant, $F=7.158$, df $=1,162$; $\mathrm{p}=0.008$; SPSS ver. 10.0; Fig. 1). This difference in algal density is also reflected in the time required for polyps to become visibly infected. At Day 19 there were no significant differences between sites $\left(\chi^{2}\right.$ test of independence, $p>0.05$ ). However, there were significant differences between sites on the subsequent $3 \mathrm{~d}$ tested and between the polyps maintained in field and in the lab on all days tested $\left(\chi^{2}\right.$ test of independence, all cases $\mathrm{p}<0.001$, with Bonferoni adjustment for multiple comparisons).

PCR amplification of ssrDNA routinely produced an approximately $1.6 \mathrm{~kb}$ product and subsequent restriction digestion of the PCR product generated fragment patterns that corresponded to the restriction patterns of the Symbiodinium clade A, B or C standards (a representative gel is available upon request from the author). Zooxanthella types found within newly settled polyps differ from those found in juvenile and adult gorgonians. Polyps were sampled periodically over 90 d. Newly-settled polyps harboring exclusively zooxanthellae in Symbiodinium clade A were only found at the shallow sites during the first $30 \mathrm{~d}$ (BRS, 8 polyps out of 19 sampled; FRS, 2 polyps out of 19 sampled; Fig. 5). The majority of the polyps sampled $(n=17)$ between 39 and $90 \mathrm{~d}$ at the sites harbored only Symbiodinium clade B zooxanthellae. After 39 d, the only observations of clade A zooxanthellae were in polyps $(n=3)$ that also harbored Symbiodinium clade B zooxanthellae. Zooxanthellae in Symbiodinium clade C were not found in any Plexaura kuna polyps. The presence of Symbiodinium clade A in polyps is in stark contrast to juvenile and adult colonies which contained only Symbiodinium clade B zooxanthellae. Juvenile gorgonians 
of 9 species, ranging in size from 0.5 to $10.8 \mathrm{~cm}(3.3 \pm$ 1.5 , mean $\pm \mathrm{SD}$ ) all harbored only zooxanthellae belonging to Symbiodinium clade B $(\mathrm{n}=131)$. This is in agreement with a previous study where adult $P$. kuna (n = 70) and adult Pseudoplexaura porosa (n = 8 ) all harbored clade B and only clade B zooxanthellae (Goulet 1999).

Establishment of the symbiosis among Pseudoplexaura porosa polyps followed a similar pattern to that observed among Plexaura kuna. The majority of $P$. porosa polyps sampled at $25 \mathrm{~d}$, harbored zooxanthellae belonging to Symbiodinium clades A, B or a mixture of $A$ and $B$ (10 out of 11, 2 with clade A alone). Zooxanthellae belonging to Symbiodinium clade C were found in a single $P$. porosa polyp that was sampled after $25 \mathrm{~d}$ in the field. After $59 \mathrm{~d}, P$. porosa polyps harbored only zooxanthellae in clade $B(n=13)$ or clades A and B together ( $\mathrm{n}=6)$. After 7 mo, 3 small gorgonians ( 0.5 to $1.5 \mathrm{~cm}, 1 \mathrm{P}$. kuna and 2 P. porosa) were recovered from the plates and all harbored only zooxanthellae belonging to Symbiodinium clade B. In both species, polyps containing a combination of zooxanthellae clades (A, B, or A and B) were found on a single settlement plate, indicating that zooxanthellae belonging to these clades were present at each site. The lack of polyps harboring solely clade A zooxanthellae after about $40 \mathrm{~d}$ is significantly different from random expectations $\left(\chi^{2}\right.$ test of independence comparing polyps with clade $\mathrm{A}$ alone and those with $\mathrm{B}$ or $\mathrm{B}+\mathrm{A}$ at the different sampling times, $\mathrm{df}=1, \mathrm{p}<0.05)$.

In summary, of the 97 polyps sampled (67 Plexaura kuna and 30 Pseudoplexaura porosa), 34 contained zooxanthellae belonging to clade A (clade A alone and in combination with clade $\mathrm{B}, P$. kuna, $\mathrm{n}=22$, $P$. porosa, $\mathrm{n}=12$ ). No adult host harbored clade A zooxanthellae (Goulet 1999) indicating that the presence of clade $\mathrm{A}$ in the newly settled polyps was not a sample artifact and that a change in the distribution of zooxanthellae clades occurs over the ontogeny of the host colony $\left(\chi^{2}\right.$ test of independence comparing zooxanthellae clades within $P$. kuna polyps over time and within adult hosts, df $=2, \mathrm{p}<0.05$; Fig. 5).

Multiple zooxanthellae initially entered the symbiosis. This was observed at several levels of resolution. Firstly, using a division rate of $0.4 \mathrm{~d}^{-1}$ (specific growth rate during exponential growth reported by Berner et al. 1993), at least 11 cells were initially needed to enter a polyp to produce the average 800 plus cells observed after $7 \mathrm{~d}$. Secondly, as noted above, some Plexaura kuna and some Pseudoplexaura porosa polyps simultaneously harbored zooxanthellae from clades A and B at all 3 San Blas sites, a result that could only occur from multiple infections (Fig. 5).

Finding zooxanthellae from Symbiodinium clades A and $\mathrm{B}$ established in a single polyp confirmed that

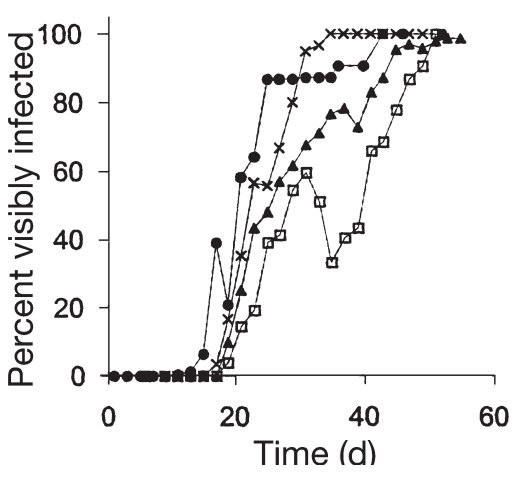

Fig. 4. Time until polyp appeared visibly infected in polyps exposed to zooxanthellae in a lab setting (500 cells $\mathrm{ml}^{-1}$, •) and in the field at 3 sites in the San Blas Islands, Panama, fore reef deep $(F R D, \square)$, fore reef shallow $(F R S, \mathbf{\Delta})$ and back reef shallow $(B R S, \times)$. Sample sizes given in 'Materials and methods'

polyps experience multiple infection events. However, when polyps harbor zooxanthellae belonging to a single clade, a finer level of resolution is needed to detect within clade variation. Among polyps containing only a single clade of zooxanthellae, DNA fingerprint analysis of zooxanthella isoclonal lines $(n=40)$ provided additional evidence of multiple infections and a second estimate of the minimum number of algal genotypes that initially enter the symbiosis. A comparison of DNA profiles from 40 zooxanthella clonal lines from 13 polyps harboring either Symbiodinium clade A or clade B zooxanthellae (10 Plexaura kuna polyps and 3 Pseudoplexaura porosa polyps) identified 1 to 2 genotypes polyp ${ }^{-1}$ (15 unique genotypes, Table 1 ). Because each polyp only contained a single zooxanthella clade,

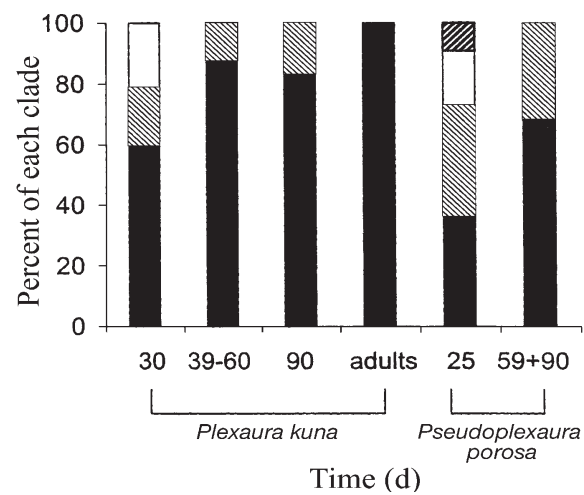

Fig. 5. A summary of the distribution of zooxanthella clades over time among newly settled Plexaura kuna and Pseudoplexura porosa polyps at 3 sites in the San Blas Islands, Panama and in 70 adult $P$. kuna collected throughout the Caribbean. The figure shows the proportion of polyps harboring a given zooxanthella clade, clade A: open bar, clade B: solid bar, clades A + B: narrow striped bar and clade C: wide striped bar 
Table 1. Results from DNA fingerprint profiles of zooxanthella isoclonal lines isolated from single polyps of Plexaura kuna and Pseudoplexaura porosa showing that individual polyps harbor different (and often multiple) genotypes. Isoclonal lines were classified by plate number, polyp number and isolate number. The genotype designation denotes a unique DNA profile, followed by the clade identification. Zooxanthella clones with the same genotype designation indicate clones that had identical DNA fingerprinting profiles (i.e. shared all bands)

\begin{tabular}{|c|c|}
\hline Isoclonal line & Genotype designation (clade) \\
\hline \multicolumn{2}{|l|}{ Plexaura kuna } \\
\hline 93.3 .1 & $1(\mathrm{~A})$ \\
\hline 93.3 .2 & $1(\mathrm{~A})$ \\
\hline 93.3 .3 & $1(\mathrm{~A})$ \\
\hline 92.5 .1 & $2(\mathrm{~B})$ \\
\hline 92.5 .6 & $3(\mathrm{~B})$ \\
\hline 92.5 .7 & 3 (B) \\
\hline 92.5 .2 & 3 (B) \\
\hline 92.5 .3 & 3 (B) \\
\hline 92.5 .4 & 3 (B) \\
\hline 92.5 .5 & 3 (B) \\
\hline 26.3.1 & $4(\mathrm{~A})$ \\
\hline 26.3 .2 & $4(\mathrm{~A})$ \\
\hline 21.4 .1 & 5 (B) \\
\hline 21.4 .2 & 5 (B) \\
\hline 44.3 .1 & 6 (B) \\
\hline 44.3 .2 & 6 (B) \\
\hline 72.2 .1 & 7 (B) \\
\hline 72.2 .2 & 7 (B) \\
\hline 118.3.1 & 8 (B) \\
\hline K6.1 & 9 (B) \\
\hline K6.2 & 9 (B) \\
\hline K6.3 & 9 (B) \\
\hline SRS20.1 & 10 (B) \\
\hline SRS20.2 & 11 (B) \\
\hline SRS20.3 & 11 (B) \\
\hline SRS20.4 & 11 (B) \\
\hline SRS20.5 & $11(\mathrm{~B})$ \\
\hline SRS20.6 & 11 (B) \\
\hline SRS20.7 & 11 (B) \\
\hline SRS20.8 & $11(\mathrm{~B})$ \\
\hline 15VIII.1 & $11(\mathrm{~B})$ \\
\hline 15VIII.3 & $11(\mathrm{~B})$ \\
\hline 15VIII.4 & $11(\mathrm{~B})$ \\
\hline 15VIII.2 & 12 (B) \\
\hline \multicolumn{2}{|c|}{ Pseudoplexaura porosa } \\
\hline 42.9 .1 & $13(\mathrm{~A})$ \\
\hline 42.9 .2 & $13(\mathrm{~A})$ \\
\hline 42.9 .3 & $13(\mathrm{~A})$ \\
\hline 102.6.1 & $14(\mathrm{~A})$ \\
\hline 102.9.1 & $15(\mathrm{~A})$ \\
\hline 102.9.2 & $15(\mathrm{~A})$ \\
\hline
\end{tabular}

in this case the multiple zooxanthella genotypes isolated within a single polyp represent within cladelevel variation. The number of isolates of a given genotype and the actual number of genotypes do not necessarily reflect the abundance of a genotype, but also depend, in part, on the ability to recover the clone through culturing.

\section{DISCUSSION}

Larval development and acquisition of algae

This study documented initial acquisition of zooxanthellae by newly settled polyps, showing that zooxanthella acquisition in the field is rapid. Zooxanthella density, within a polyp, steadily increased so that by $14 \mathrm{~d}$, many of the polyps appeared visibly infected. Plexaura kuna and Pseudoplexaura porosa polyps were visibly infected after 11 to $19 \mathrm{~d}$, but zooxanthellae were present much earlier than this as evidenced by cell counts made after $7 \mathrm{~d}$ (Fig. 1). Constant exposure to zooxanthellae was not necessary, as algal acquisition occurred over a very short time. Three day old planulae that were maintained in the field for 3 to $7 \mathrm{~d}$ and then returned to the lab, subsequently became visibly infected indicating that initial uptake occurs rapidly (Fig. 1). Furthermore, successful symbioses were established in polyps that were exposed to zooxanthellae for only $1 \mathrm{~h}$ (Fig. 3) at cell densities of 100 cells $\mathrm{ml}^{-1}$. These initial algal densities were substantially lower than those used in most previous studies where algal densities ranged from $10^{3}$ to $10^{4}$ cells $\mathrm{ml}^{-1}$ (Colley \& Trench 1983, Fitt 1984, 1985). Our results are similar to those reported by Kinzie et al. (2001) where infection occurred at concentrations as low as 10 cells $\mathrm{ml}^{-1}$ and our observations mirror those reported for the establishment of symbioses in other cnidarians and sponges (Kinzie 1974, Fitt 1984, 1985, Colley \& Trench 1985, Alino \& Coll 1989, Benayahu et al. 1989, Hill \& Wilcox 1998, Schwarz et al. 1999).

Although infection occurred at low algal concentrations, differences in time to become visibly infected indicates that zooxanthella density increased with increasing exposure to algae. When polyps were repeatedly exposed to algae, they continued to acquire zooxanthellae and thus became visibly infected sooner. Montgomery \& Kremer (1995) and Kinzie et al. (2001) also found that density of zooxanthella innoculum affected infection rate. We did not see a correlation of exposure time and time to visible infection in the experiments when polyps were incubated in microtiter plates. In this experiment, both polyps exposed to TPA and those maintained under the same experimental conditions in sterile microtiter plates but without exposure to the chemical, TPA, showed misshaped polyps and few expanded polyps. These similarities in development suggest a container effect as opposed to an effect of the chemical, TPA. Although an effect of exposure time was not seen in the experiment where polyps were reared in microtiter plates and TPA was used to induce larval settlement, this experiment is significant as it establishes that uptake leading to 'visible infection' can occur over relatively short time 
periods $(1 \mathrm{~h})$ and at relatively low concentrations of algae $\left(100\right.$ cells ml $\left.^{-1}\right)$. At these concentrations, time to visible infection was similar to that observed in the field or in no zooxanthellae added controls. Finally this experiment also verified that polyps not exposed to zooxanthellae remain aposymbiotic.

\section{Are in situ densities of zooxanthellae low?}

The acquisition of zooxanthellae by newly settled polyps demonstrates the presence of free-living zooxanthellae, but neither the source of the zooxanthellae nor in situ zooxanthella densities are known. Potential sources include zooxanthellae released by cnidarians (Steele 1977, Hoegh-Guldberg et al. 1987, HoeghGuldberg \& Smith 1989, Stimson \& Kinzie 1991, Davy et al. 1997, Maruyama \& Heslinga 1997), those excreted by fish (Muller-Parker et al. 1996, Augustine \& Muller-Parker 1998), and possibly populations in the benthos (Carlos et al. 1999). Given that infection rate is correlated to zooxanthella concentrations (Montgomery \& Kremer 1995, Kinzie et al. 2001), a comparison of the rates of zooxanthella acquisition under known zooxanthella concentrations with that observed in situ provides a rough estimate of zooxanthella abundance in the field. The lower infection rates and lower number of zooxanthellae in polyps maintained in the field (Fig. 1) suggest that the density of zooxanthellae available in the field was lower than that introduced into our containers (i.e. $<500$ cells ml $^{-1}$ ).

Examination of the results of our 'no zooxanthellae added' controls also provides insight into the abundance of zooxanthellae in the field. We performed 2 types of controls. In the first treatment, the settlement substrate and the water were potential sources of zooxanthellae, while in the second the polyps were maintained in filtered seawater in sterile microtiter plates. No zooxanthella uptake was observed in the latter, but zooxanthellae were observed in polyps in 3 out of 4 containers from the first controls. The incidental infection of these 'no zooxanthellae added' controls lends support to the hypothesis that zooxanthellae reside in the benthos (such as the surface of the settlement plates) and that field densities are much lower than those normally used in lab infection studies. Polyps in 3 of the 4 containers of 'no zooxanthellae added' controls acquired zooxanthellae, although at a slower rate than those polyps maintained in the laboratory or in situ (after 17 to $31 \mathrm{~d}$ ). Although zooxanthellae were not added to the control treatments, the plates used as a settlement substratum for the polyps had been maintained on the reef for 6 mo to 3 yr prior to the experiment, allowing them to develop a coating of crustose coralline algae to enhance attachment of larvae (Lasker
\& Kim 1996). These plates were brushed and rinsed before use, but some zooxanthellae apparently remained on the plates. After the infection of the controls was verified, 3 plates were rinsed vigorously with a jet of $60 \mathrm{ml}$ of filtered seawater and cells that visibly resembled zooxanthellae were recovered (mean, $3.96 \times 10^{4}$ cells $\mathrm{cm}^{-2}$ of plate; range, 0.3 to $10.7 \times 10^{4}$ cells cm${ }^{-2}$ ). These data suggest the ubiquity of zooxanthellae in the field and that polyps have the ability to readily acquire zooxanthellae even when the zooxanthellae are present in relatively low numbers.

\section{The ontogenic expression of specificity}

A wealth of literature exists that demonstrates cnidarians and other hosts are capable of acquiring and maintaining symbioses with a range of the symbiotic dinoflagellates (Kinzie 1974, Schoenberg \& Trench 1976, Kinzie \& Chee 1979, Schoenberg \& Trench 1980b, Colley \& Trench 1983, Fitt 1984, 1985, Davy et al. 1997). The consensus of these studies is that the initial acquisition is only weakly selective in the sense that many distantly related algae within the genus Symbiodinium can enter the host (see above references). Despite this apparent lack of specificity at initial acquisition, under natural conditions, host-symbiont specificity is evident. For example, zooxanthellae belonging to many species and clades are found on the reef, yet the adults of any given species (with a few exceptions) harbor zooxanthellae from a single clade. For example, all adult Plexaura kuna harbor zooxanthellae belonging to clade $B$, regardless of where the adult is found (over depth or geographically) (Goulet 1999). Furthermore, this same observation is true for the vast majority of Caribbean octocorals examined to date (more than 36 species throughout the Caribbean, Goulet 1999) where each host species harbors the same type of zooxanthellae (i.e. belonging to a given clade) regardless of depth or geographic location (Goulet 1999).

We have demonstrated that under natural conditions, initial acquisition of zooxanthellae does not reflect adult host specificity, with newly settled gorgonian polyps naturally acquiring zooxanthellae belonging to all 3 common algal clades during early ontogeny. Over time, the number of polyps containing only zooxanthellae in clade A or clades A + B diminished. By the time a gorgonian was 3 to $10 \mathrm{~cm}(\sim 1 \mathrm{yr})$ only zooxanthellae belonging to clade $\mathrm{B}$ were detected, regardless of location or depth. Furthermore, the absence of even low densities of zooxanthellae belonging to Symbiodinium clade A was verified in a subset of these juvenile gorgonian samples using a taxon-specific primer to amplify ssrDNA (Coffroth, 
Santos \& Goulet unpubl. data). In those analyses, DNA from 31 small gorgonians representing 4 species was amplified with both Symbiodinium clade A- and Bspecific primers (Coffroth, Santos \& Goulet unpubl. data). In all cases, only zooxanthellae belonging to Symbiodinium clade B were detected.

Individual polyps simultaneously contain zooxanthellae from different clades and multiple genotypes were discerned within clades. The high zooxanthella diversity within newly settled polyps again demonstrates that polyps initially acquired multiple algal cells. Furthermore, variability within a clade exists as single polyps harbored multiple zooxanthella genotypes within a single clade and these genotypes varied among polyps (based on our DNA fingerprint analysis). Belda-Baillie et al (1999), studying the tridacnid-zooxanthella symbiosis, also found that multiple zooxanthella genotypes initially entered the symbiosis when juvenile tridacnid clams were exposed to 'wild' zooxanthellae. When the algal composition within a clam was examined after 3,6 and 9 mo (through cell isolations and culturing), clams had acquired multiple strains/genotypes. Further work is needed to establish if the intracladal variation in zooxanthella population structure observed is the result of a random ontogenetic change in zooxanthella taxonomic diversity or is a response to environmental cues.

Although polyps at all sites eventually harbored only zooxanthellae belonging to Symbiodinium clade B, there appeared to be some site (environment) related trends in initial acquisition. Initially polyps containing zooxanthellae in clade B or a mixture of A and B could be found at all sites demonstrating that these algal types were present at all sites. However, the only cases of polyps harboring only clade A zooxanthellae were from the shallow reef sites (fore and back reefs). The single case of a polyp initially acquiring zooxanthellae belonging to clade $\mathrm{C}$ occurred at the shallow forereef site. These results may reflect random variation in both uptake and in our sampling or may reflect in situ abundances of the clade at the sites or may represent an early developmental requirement of the polyps in response to an environmental cue. Determining the reason for this diversity will require further research.

The establishment of the host-symbiont specificity observed in cnidarians has been proposed to occur through a series of steps (Schoenberg \& Trench 1980b, Fitt 1985, Trench 1988, 1997). Initially a host will endocytose a relatively broad range of symbionts that possess the correct 'signal'. This 'signal' may be very generic as laboratory assays demonstrate that a diverse group of algae can initially enter the host. A subset of these algae become established (i.e. divide) within host cells and then a selection/change occurs which determines the final complement of symbionts, presumably excluding the less effective symbionts and selecting the more effective symbionts. This reduces zooxanthella variation within a host and leads to the specificity and persistence we see in many systems (Schoenberg \& Trench 1980b, Trench 1988, Douglas 1998). Results of laboratory experiments and observations of the zooxanthella composition within a host under natural conditions support this scenario.

Our results of in situ infection confirm the hypothesized early ontogenic change in zooxanthella diversity of the zooxanthella complement within a host after initial acquisition. In the gorgonians Plexaura kuna and Pseudoplexaura porosa the initial establishment of the symbiosis was dynamic and the expression of specificity occurred over time. Initially the host acquired zooxanthellae belonging to different algal clades and different genotypes within clades. Within the first year, probably sooner, the initial within polyp diversity was reduced to zooxanthellae belonging to a single Symbiodinium clade, establishing the specificity that has been regularly observed in adult colonies. The fact that this within host early ontogenic change in zooxanthella diversity occurred over a range of environments, indicates that the process is one of a host/algal interaction and not the result of a stochastic event nor does the ultimate outcome reflect environment specific selection. It has been suggested that the final zooxanthella complement is determined by the competitive abilities of the zooxanthellae, with the one that survived and grew best under the given host condition establishing the symbiosis (Schoenberg \& Trench 1980b, Fitt 1985, Trench 1987). However, other mechanisms for the establishment of the final complement must also be examined, including active selection/exclusion by the host based on algal type, variation in the abundance of algal types, lower survival of polyps containing zooxanthellae from other clades, a combination of the above or some other undescribed mechanism.

Acknowledgements. We thank the Republic of Panama and the Kuna Indians for permission to work in the San Blas Islands, Panama and the staff and scientists at the Smithsonian Tropical Research Institute for their assistance, especially R. Tapia in the San Blas and N. Knowlton and the associates in her lab at Naos. This project could not have been completed without the able assistance of many people, including L. Bright, M. Boller, D. Brancato, A. Dweliski, K Giles, C. Gorham, D. Goulet, C. Hickox, S. Hurley-Leslie, G. Keller, M. Kolonski, H. Lasker, C. Reynolds, O. Rios-Cardenas, C. Gutierrez-Rodriguez, T. Snell, T. Swain and K. Watts. We thank them all. The manuscript has been improved by comments from L. Bright, D. Goulet, R. A. Kinzie III, H. Lasker, G. May, C. Gutierrez Rodriguez and 3 anonymous reviewers. This work was supported by NSF OCE-9530057 and OCE9907319 (MAC), American Museum of Natural History, Lerner Gray Fund for Marine Research, Mark Diamond Research Fund and Houston Underwater Club and Seaspace Scholarship (TLG) and NSF Minority Fellowship (SRS). 


\section{LITERATURE CITED}

Alino PM, Coll JC (1989) Observations of the synchronized mass spawning and post settlement activity of octocorals on the great barrier reef, Australia: Biological Aspects. Bull Mar Sci 45:697-707

Augustine L, Muller-Parker G (1998) Selective predation by the mosshead sculpin Clinocottus globiceps on the sea anemone Anthopleura elegantissima and its two algal symbionts. Limnol Oceanogr 43:711-715

Baker A (1999) Symbiosis ecology of reef-building corals. PhD Dissertation, University of Miami

Baker AC, Rowan R (1997) Diversity of symbiotic dinoflagellates (Zooxanthellae) in scleractinian corals of the Caribbean and Eastern Pacific. Proc 8th Int Coral Reef Symp 2:1301-1306

Baker AC, Rowan R, Knowlton N (1997) Symbiosis ecology of two Caribbean acroporid corals. Proc 8th Int Coral Reef Symp 2:1295-1300

Baumann P, Moran NA, Baumann L (1997) The evolution and genetics of aphid endosymbionts. Bioscience 47:12-20

Belda-Baillie C, Sison M, Silvestre V, Villamor K, Monje K, Gomez E, Baillie B (1999) Evidence for changing symbiotic algae in juvenile tridacnids. J Exp Mar Biol Ecol 241: 207-221

Benayahu Y, Achituv Y, Berner T (1989) Metamorphosis of an octocoral primary polyp and its infection by algal symbiosis. Symbiosis 7:159-169

Berner T, Baghdasrian G, Muscatine L (1993) Repopulation of a sea anemone with symbiotic dinoflagellates: analysis by in vivo fluorescence. J Exp Mar Biol Ecol 170:145-158

Billinghurst Z, Douglas AE, Trapido-Rosenthal HG (1997) On the genetic diversity of the symbiosis between the coral Montastrea cavernosa and zooxanthellae in Bermuda. Proc 8th Int Coral Reef Symp 2:1291-1294

Brazeau DA, Lasker HR (1989) The reproductive cycle and spawning in a Caribbean gorgonian. Biol Bull 176:1-7

Carlos AA, Baillie BK, Kawachi M, Maruyama T (1999) Phylogenetic position of Symbiodinium (Dinophyceae) isolates from tridacnids (Bivalvia), cardids (Bivalvia), a sponge (Porifera), a soft coral (Anthozoa), and a free-living strain. J Phycol 35:1054-1062

Chapela IH, Rehner RA, Schultz TR, Mueller UG (1994) Evolutionary history of the symbiosis between fungus-growing ants and their fungus. Science 266:1691-1694

Clark MA, Moran NA, Baumann P, Wernegreen JJ (2000) Cospeciation between bacterial endosymbionts (Buchnera) and a recent radiation of aphids (uroleucon) and pitfalls of testing for phylogenetic congruence. Evolution 54: $517-525$

Coffroth MA, Lasker HR, Diamond ME, Bruenn JA, Bermingham E (1992) DNA Fingerprints of a gorgonian coral-a method for detecting clonal structure in a vegetative species. Mar Biol 114:317-325

Coffroth MA, Santos SR (1997) Early ontogeny of zooxanthellae-coral symbiosis - a preliminary report. Am Zool 37: $11 \mathrm{~A}$

Colley NJ, Trench RK (1983) Selectivity in phagocytosis and persistence of symbiotic algae by the scyphistoma stage of the jellyfish Cassiopeia xamachana. Proc R Soc Lond B 219:61-82

Colley NJ, Trench RK (1985) Cellular events in the reestablishment of a symbiosis between a marine dinoflagellate and a coelenterate. Cell Tissue Res 239:93-103

Darius HT, Dauga C, Grimont PAD, Chungue E, Martin PMV (1998) Diversity in symbiotic dinoflagellates (Pyrrhophyta) from seven scleractinian coral species: restriction enzyme analysis of small subunit ribosomal RNA genes. J Euk Microbiol 45:619-627

Davy SK, Lucas IAN, Turner JR (1997) Uptake and persistence of homologous and heterologous zooxanthellae in the temperate sea anemone Cereus pedunculatus (Pennant). Biol Bull 192:208-216

Douglas AE (1998) Host benefit and the evolution of specialization in symbiosis. Heredity 81:599-603

Fitt WK (1984) The role of chemosensory behavior of Symbiodinium microadriaticum, intermediate hosts, and host behavior in the infection of coelenterates and molluscs with zooxanthellae. Mar Biol 81:9-17

Fitt WK (1985) Effect of different strains of the zooxanthella Symbiodinium microadriaticum on growth and survival of their coelenterate and molluscan hosts. Proc 5th Int Coral Reef Congr 6:131-136

Fitt WK, Trench RK (1981) Spawning, development, and acquisition of zooxanthellae by Tridacna squamosa (Mollusca, Bivalvia). Biol Bull 161:213-235

Goulet TL (1999) Temporal and spatial stability of zooxanthellae in octocorals. PhD thesis, State University of New York at Buffalo

Goulet TL, Coffroth MA (1997a) Geographic distribution of zooxanthella genotypes in octocorals. Am Zool 37:73A

Goulet TL, Coffroth MA (1997b) A within colony comparison of zooxanthella genotypes in the Caribbean gorgonian Plexaura kuna. Proc 8th Int Coral Reef Symp 2:1331-1334

Guillard RRL (1975) Culturing dinoflagellates. In: Smith WL, Chanley $\mathrm{MH}$ (eds) Culture of marine invertebrates. Plenum, New York, p 338

Henning G, Hoffmann DK, Benayahu Y (1996) The phorbol ester TPA induces metamorphosis in Red Sea coral planulae (Cnidaria: Anthozoa). Experientia 52:744-749

Hill M, Wilcox T (1998) Unusual mode of symbiont repopulation after bleaching in Anthosigmella varians: acquisition of different zooxanthellae strains. Symbiosis 25: 279-289

Hinkle G, Wetterer JK, Schultz TR, Sogin ML (1994) Phylogeny of the attine ant fungi based on analysis of small subunit ribosomal RNA gene sequences. Science 266: 1695-1697

Hoegh-Guldberg O, Smith GJ (1989) The effect of sudden changes in temperature, light and salinity on the population density and export of zooxanthellae from the reef corals Stylophora pistillata Esper and Seriatopora hystrix Dana. J Exp Mar Biol Ecol 129:279-303

Hoegh-Guldberg O, McCloskey L, Muscatine L (1987) Expulsion of zooxanthellae by symbiotic cnidarians from the Red Sea. Coral Reefs 5:201-204

Kapela W, Lasker HR (1999) Size-dependent reproduction in the Caribbean gorgonian Pseudoplexaura porosa. Mar Biol 135:107-114

Kinzie RA III (1974) Experimental infection of aposymbiotic gorgonian polyps with zooxanthellae. J Exp Mar Biol Ecol 15:335-345

Kinzie RA III, Chee GS (1979) The effect of different zooxanthellae on the growth of experimentally reinfected hosts. Biol Bull 156:315-327

Kinzie RA III, Takayama M, Santos SR, Coffroth MA (2001) The adaptive bleaching hypothesis: Experimental tests of critical assumptions. Biol Bull 200:51-58

Lasker HR, Kim K (1996) Larval development and settlement behavior of the gorgonian coral Plexaura kuna (Lasker, Kim and Coffroth). J Exp Mar Biol Ecol 207:161-175

Lasker HR, Brazeau DA, Calderon J, Coffroth MA, Coma R, Kim K (1996) In situ rates of fertilization among broadcast spawning gorgonians. Biol Bull 190:45-55 
Maruyama T, Heslinga GA (1997) Fecal discharge of zooxanthellae in the giant clam Tridacna dersas, with reference to their in situ growth rate. Mar Biol 127:473-477

McNally KL, Govind NS, Thomé PE, Trench RK (1994) Small subunit ribosomal DNA sequence analyses and a reconstruction of the inferred phylogeny among symbiotic dinoflagellates (Pyrrophyta). J Phycol 30:316-329

Mitter C, Farrell B, Futuyma DJ (1991) Phylogenetic studies of insect-plant interactions: insights into the genesis of diversity. Trends Ecol Evol 6:290-293

Montgomery MK, Kremer PM (1995) Transmission of symbiotic dinoflagellates through the sexual cycle of the host scyphozoan Linuche unuiculata. Mar Biol 124: $147-155$

Muller-Parker G, Lee KW, Cook CB (1996) Changes in the ultrastructure of symbiotic zooxanthellae (Symbiodinium sp., Dinophyceae) in fed and starved sea anemones maintained under high and low light. J Phycol 32:987-994

Peek AS, Feldman RA, Lutz RA, Vrijenhoek RC (1998) Cospeciation of chemoautotrophic bacteria and deep sea clams. Proc Natl Acad Sci 95:9962-9966

Provasoli L, Yamasu T, Manton I (1968) Experiments on the resynthesis of symbiosis in Voncoluta roscoffensis with different flagellate cultures. J Mar Biol Assoc UK 48: 465-479

Provorov NA (1998) Coevolution of rhizobia with legumes: facts and hypotheses. Symbiosis 24:337-368

Rowan R (1991) Molecular systematics of symbiotic algae. J Phycol 27:661-666

Rowan R (1998) Diversity and ecology of zooxanthellae on coral reefs. J Phycol 34:407-417

Rowan R, Knowlton N (1995) Intraspecific diversity and ecological zonation in coral-algal symbiosis. Proc Natl Acad Sci USA 92:2850-2853

Rowan R, Powers DA (1991a) A molecular genetic classification of zooxanthellae and the evolution of animal-algal symbioses. Science 251:1348-1351

Rowan R, Powers DA (1991b) Molecular genetic identification of symbiotic dinoflagellates (zooxanthellae). Mar Ecol Prog Ser 71:65-73

Rowan R, Powers DA (1992) Ribosomal-RNA sequences and the diversity of symbiotic dinoflagellates (Zooxanthellae). Proc Natl Acad Sci USA 89:3639-3643

Rowan R, Knowlton N, Baker A, Jara J (1997) Landscape ecology of algal symbionts creates variation in episodes of coral bleaching. Nature 388:265-269

Sadler LA, McNally KL, Govind NS, Brunk CF, Trench RK (1992) The nucleotide sequence of the small subunit ribosomal RNA gene from Symbiodinium pilosum, a symbiotic dinoflagellate. Curr Genet 21:409-416

Schoenberg DA, Trench RK (1976) Specificity of symbioses between marine cnidarians and zooxanthellae. In: Macke

Editorial responsibility: Otto Kinne (Editor),

Oldendorf/Luhe, Germany
GO (ed) Coelenterate ecology and behavior. Plenum, New York, p 423-432

Schoenberg DA, Trench RK (1980a). Genetic variation in Symbiodinium (=Gymnodinium) microadriaticum Freudenthal, and specificity in its symbiosis with marine invertebrates. I. Isoenzyme and soluble protein patterns of axenic cultures of $S$. microadriaticum. Proc R Soc Lond B 207:405-427

Schoenberg DA, Trench RK (1980b) Genetic variation in Symbiodinium (=Gymnodinium) microadriaticum Freudenthal, and specificity in its symbiosis with marine invertebrates. III. Specificity and infectivity of Symbiodinium microadriaticum. Proc R Soc Lond B 207:445-460

Schwarz JA, Krupp DA, Weis VM (1999) Late larval development and onset of symbiosis in the scleractinian coral Fungia scutaria. Biol Bull 196:70-79

Steele RD (1977) The significance of zooxanthella-containing pellets extruded by sea anemones. Bull Mar Sci 27: 591-594

Steen R (1987) Evidence for facultative heterotrophy in cultured zooxanthellae. Mar Biol 95:15-23

Stimson J, Kinzie Ra III (1991) The temporal pattern and rate of release of zooxanthellae from the reef coral Pocillopora damicornis (Linneaus) under nitrogen-enrichment and control conditions. J Exp Mar Biol Ecol 153:63-74

Trench RK (1971) The physiology and biochemistry of zooxanthellae symbiotic with marine coelenterates III. The effect of homogenates of host tissues on the excretion of photosynthetic products in vitro by zooxanthellae from two marine coelenterates. Proc R Soc Lond B 177: 251-264

Trench RK (1987) Dinoflagellates in non-parasitic symbioses. In: Taylor FJR (ed) The biology of dinoflagellates. Blackwell Scientific, Oxford, p 530-570

Trench RK (1988) Specificity in dinomastigote-marine invertebrate symbioses: an evaluation of hypotheses of mechanisms involved in producing specificity. In: Scannerinni S, Smith DC, Bonfante-Fasolo P, Gianninazzi-Pearson V (eds) Cell to cell signals in plant, animal and microbial symbiosis. NATO Asi Series H, Cell Biology, Vol 17. Springer-Verlag, Berlin, p 325-346

Trench RK (1997) Diversity of symbiotic dinoflagellates and the evolution of microalgal-invertebrate symbioses. Proc 8th Int Coral Reef Symp 2:1275-1286

Trench RK, Colley NJ, Fitt WK (1981) Recognition phenomena in symbioses between marine invertebrates and 'zooxanthellae'; uptake, sequestration and persistence. Ber Dtsch Bot Ges 94:529-545

Zardoya R, Costas E, Lopezrodas V, Garridopertierra A, Bautista JM (1995) Revised dinoflagellate phylogeny inferred from molecular analysis of large-subunit ribosomal-RNA gene-sequences. J Mol Evol 41:637-645

Submitted: June 26, 2000; Accepted: March 5, 2001

Proofs received from author(s): October 5, 2001 